\title{
CONSIDERATIONS ABOUT THE ENVIRONMENTAL IMPACT CAUSED BY EXTRACTING SAND
}

\section{CONSIDERAÇÕES SOBRE O IMPACTO AMBIENTAL PROVOCADO PELA EXTRAÇÃO DE AREIA}

\author{
Dalya Ketty Barros \\ dalyabarros@bol.com.br \\ Marcus Vinicius Ferreira Silva \\ mrkviny@bol.com.br \\ Renata Napoleão \\ ronairalima@yahoo.com.br \\ Ronaira Aline Lima Viana \\ escala.pi@uol.com.br \\ Josimar Ribeiro de Almeida \\ jralmeida@usp.br \\ Observatório Urbano/UERJ/UN-Habitat \\ Gustavo Aveiro Lins \\ gu.lins@terra.com.br \\ CEDERJ/SEE-RJ/CEDAE \\ Manoel Gonçalves Rodrigues \\ manoel.grodrigues@gmail.com \\ Observatório Urbano/UERJ/UN-Habitat
}

\begin{abstract}
Environmental problems currently constitute one of the biggest concerns of the global scientific ambient. In this sense, this work had as objective the analysis of the environmental impacts arising from mineral extraction and changes in physical and biotic environment. The results through the method of "check-list" showed that although such projects bring radical environmental effects is possible to minimize the negative effects of mining, at all stages of the project, with solutions based on the analysis of monitoring and correction, for satisfactory results and the re-composition of the striking scenery. The main conclusion is that this study can be used as a theoretical framework to support the process of environmental licensing of this type of venture.
\end{abstract}

Keywords: Impacts, environment, social value. 


\section{RESUMO}

Os problemas ambientais constituem atualmente uma das maiores preocupações do âmbito do meio cientifico global. Neste sentido, este trabalho teve como objetivo a analise dos impactos ambientais decorrentes da extração mineral e as alterações deste no meio físico e biótico. Os resultados por meio do método do "check-list" demonstraram que embora projetos desta natureza tragam efeitos radicais ao meio ambiente é possível, minimizar os efeitos negativos da mineração, em todas as etapas do empreendimento, com soluções baseadas nas analises de acompanhamento e correção, para obtenção de resultados satisfatórios e a recomposição do cenário impactante. A principal conclusão é a de que este estudo pode ser utilizado como referencial teórico para subsidiar o processo de licenciamento ambiental desse tipo de empreendimento.

Palavras-Chave: Impactos, ambiente, valor social.

\section{INTRODUCTION}

This work contains the theoretical literature based support, made in books and articles that deal with mineral extraction on the World Wide Web and internet. An analysis of the environmental impact of sand extraction was taken, which was compared with the relevant legislation.

The mineral extraction is an old activity and responsible for great impacts caused to the environment. These are the several impacts caused by extracting sand key: the removal of vegetation, changes in the structure of the Sun, the interference on the fauna, soil compaction and instability of the banks and slopes.

This study aims to analyze the environmental impacts, resulting from the installation and operation of mining activity.

\section{REVIEW OF LITERATURE}

Sand mining occurs in places where there was the deposition of eroded sedimentary material along the geological ages, usually near the bottom of valleys and rivers, often coinciding with the riparian forests, considered areas of permanent preservation (APP).

The Forest Code and CONAMA Resolution 302/2002 consider that the permanent preservation areas must remain untouched. However, the CONAMA Resolution $369 / 2006$ authorized the use in sand mining, deeming it of social interest. However the sand mining has just been generating numerous socio-economic and environmental impacts, some positive, others negative, as the present study that considers social and environmental welfare protection, which covers both the human 
being and as the environment in which he lives.

Mining ventures can cause environmental impacts during operation and when disabled. Environmental impact is understood as any adverse or beneficial consequence, which results or may result from the interaction of environmental aspects or elements of processes, products, services, and operation of an organization with which it has ability to influence (REIS et al 2005).

According to REIS (2005), environmental impacts can be divided into physical, socioeconomic impacts and biotic environment.

\section{Socioeconomic Impacts:}

- Generation of taxes;

- Generation of employments;

- Generation of raw-material.

- Area of extraction out of polygonal boundaries, changing the natural landscape.

\section{Impact on the Physical Environment:}

Modification in the structure and fertility of the soil, noise pollution, groundwater level change, erosive process, changes in water quality, contamination of water table scarf, solid waste generation, change of natural drainage system.

\section{Impact on Biotic Environment:}

Changes of flora, offset, and flora and fauna behavioral alteration, species inadequate to recover PPA, PPA degradation (transit of people and animals).

According to CPRM (2002), the main problems from mining can be included in five categories: water pollution, air pollution, noise pollution, subsidence of the ground, fires caused by coal and radioactive waste.

According to the Brazilian legislation (CONAMA Resolution 001, January 23rd, 1986) it is considered environmental impact:

For the purposes of this resolution, environmental impact is considered to be any change in the physical, chemical and biological characteristics of the environment, caused by any form of matter or energy resulting from human activities, directly or indirectly, affect: 
I - health, safety and well-being of the population;

II - the social and economic activities;

III - the biota;

IV - aesthetic and sanitary conditions of the environment;

$\mathrm{V}$ - the quality of environmental resources.

Then, the concept of environmental impact refers exclusively to the effects of human action on the environment. Therefore, natural phenomena, such as storms, floods, forest fires from natural reason, earthquakes and others, although they can change the highlighted alterations, are not characterized as environmental impact.

In Brazil, mining, in general, is subject to a set of regulations, where the three levels of State power have duties with respect to mining and the environment.

At the federal level, the first legal device associated with the Environmental Impact Assessment took place through the adoption of the Law 6,938, August $31^{\text {st }}$, 1981, establishing the National Environment Policy and creates the SISNAMA (Sistema Nacional de Meio Ambiente) as executing agency. Note the Federal Decree no 88,351 , June $1^{\text {st }}, 1983$, establishes the CONAMA and defines its powers. These basically aim at the establishment of definitions, responsibilities, basic criteria and general guidelines for use and implementation of the National Policy for the Environment. Thus, in the use of its attributions, CONAMA has rendered several regulations through resolutions.

Among those, the CONAMA Resolution o 001, January 23rd, 1986, and the CONAMA Resolution № 237, December 19th, 1997 establish definitions, responsibilities, basic criteria and general guidelines for use and implementation of Assessment and Environmental of Impact Studies.

According to the III subparagraph of the third article of CONAMA Resolution $\mathrm{n}^{\circ}$ 237/97:

Environmental Studies are all and any studies relating to environmental aspects related to location, installation, operation and expansion of an activity or project, presented as allowance for the required license analysis, such as environmental report, and environmental control project, preliminary environmental report, environmental management plan, environmental 
diagnosis, management plan, degraded area recovery plan and preliminary risk analysis.

The environmental licensing is one of the instruments of the national environmental policy (Law №. 6,938/81), which can be considered as a member of the preventive procedures within the process of environmental control.

\section{JUSTIFICATIVE}

Mineral extraction is without a doubt, an activity essential to the survival of modern man, in view of the importance assumed by the mineral assets in practically all human activities. It is very common at their ending, to notice specific aspects as the volume excavated and the physical appearance of occupied areas by buildings, among others.

The extraction activities have a vital role in social aspects and influence on the behavior of society.

However, mining is an activity of detrimental potential action to the environment, and with every order modifiers, effects which occur in steps of sand extraction. In this sense, it is affirmed the importance of a plan that can tend to neutralize the impact of every order, leading to a productive extraction and reconciled with the environment. Aims above all to give efficiency and effectiveness activities with solutions based on the analysis of monitoring and correction of course for satisfactory results and in a sustainable way.

The present work seeks to contribute to the improvement of the security of environment.

\section{MATERIAL AND METHODS}

The data were analyzed by descriptive and theoretical way. Secondary sources used were from the internet, the records of organizations and legal aspects (from books). The sand extraction process has mining plan in heights, with the aim of future recovery of vegetation coverage. The main environmental impact is the removal of the vegetation in the areas already limited as mining project specification approved by Decree of Mining and environmental restrictions, therefore being the exploitation linked to the aspect of visual impact, during the mining process, since the long-term 
recovery plan will reverse this impact.

Sand extraction is made both in the beds of the rivers as in the deposits of banks or mudslides, using traditional extraction methods and widely disseminated. The sand is taken from your deposit with the use of dredgers and is generally referred to the washing process for the removal of impurities.

\section{RESULTS AND DISCUSSION}

Some mitigating and controlling measures can be used in areas of sand extraction like the protection of the areas of permanent preservation, the preparation of tree nurseries, the fauna management, the soil storage, the recovering of the cultivated area and the slopes stability (BRUSCHI and PEIXOTO, 1997).

\section{Environmental impacts prognosis}

In this prognosis the potential impacts will be identified from the direct relationship of the actions that will be performed by the entrepreneur in different phases and steps of the installation and operation of the dredging process so that the mitigating measures will be best defined.

\section{Description of the potential impacts}

According to the hit factors, a description of the potential impacts identified in the different phases of the project, aiming to identify the main relevant mitigating measures and set the respective recommendations will be presented as follows.

\section{IMPACTS RELATED TO THE PHYSICAL ENVIRONMENT}

\section{Air Quality Changes}

During some activities that are part of the installation and operation of Dredger of "Deolino", the emission of gases and particulate material are foreseen. The gases are deriving of the engine of dredger in operation, where carbon monoxide (CO) and the carbon dioxide (CO2) associate to the particulate material (soot) are highlighted. Another way to reduce air quality refers to the dust emission in material offsets and traffic of trucks and machines, by the access road to dredger. At the time of 
application of Double Surface Treatment (DST), the gases volatilize themselves, going on to compose the atmosphere.

Dust is another component object of concern, not only that coming from the handling of building materials, as well as the emitted during the displacement of vehicles, machines and transportation of various materials, which may cause its dispersion along the route. It can be harmful for the health of workers and the local population, as the vegetation and fauna populations reached, which will tend to acquire layers of dust on the leaves, slowing the processes of respiration, transpiration and photosynthesis, damaging in the animals that dwell in surroundings of the enterprise.

\section{Production of noises and vibrations}

During the implantation and operation of the dredger, there will be the production of noise and vibrations, arising from the use of trucks, machines and the operation of the motor. The engine of the dredger and the noise dissipated by the moving trucks are examples of these impact generators. These effects will be felt in the area of direct influence by workers working in the enterprise, as well as by the components of the fauna that can be chased away to more distant habitats.

\section{Soil Quality Change}

The activities involving vehicles, machines and equipment in the phases of dredgers operation, during the corrective equipment maintenance, provoke possible risks of soil contamination. Such fact will occur if there is the inefficient administration of storage and, when the maintenance of machines and equipment is not made with ability, as well as, without the necessary writs of prevention, being able to cause spilling of fuels, oils and greases on the soil.

The alterations suffered by the ground will culminate with the erosive processes outburst. These processes will initiate for occasion of the implantation of the activities related to the opening of ways of services.

In result of the material brought from these erosions, once it is installed, there will have a greater cargo of particulate material to the water course, causing siltation and increase of waters turbidity in case that it has in the near areas.

\section{Water Quality Change}

The earth-moving works, the installation and operation of the dredger, the 
construction of surface drainage works and water obtaining may birth the charging processes of solids to the watercourse, intercepted near the project, causing siltation and increased turbidity of water, arising from the suspended particles.

On the other hand the operation of machines and vehicles can generate effluents containing toxic substances or pollutants, originated from leaking by improper handling or disposal of oil, lubricants, grease and diesel oil, which could reach the watercourse of the river, changing its quality standards.

\section{Solid Waste Generation}

During operation of the equipment that makes up the dredge, especially the splitter box operation, there may be leftover material, equipment packaging, as also materials such as warm food packages, disposable cups, beverage cans, bottles of motor oil and lubricants, etc., that can be thrown out in the areas by the staff of the dredger and current population.

These materials when deposited in inappropriate locations may cause damage to the environment, such as: transport to the watercourse, compromising the hydric resources, visual pollution, soil pollution and the risk of accidents with domestic and wild animals.

\section{Landscape Shift}

Especially with the installation and operation of a dredge, changes in natural conditions of the landscape, with the construction of support structures and local access road project, deforestation, causing visual changes in the environment are seen.

\section{IMPACTOS RELATED TO THE BIOTIC ENVIRONMENT}

\section{Removal of vegetation and site cleaning}

At the time of construction of the project, the elimination of the vegetation of the area takes place, about 0.5 ha; this fact will cause the chasing of the local fauna specimens to other habitats. 


\section{IMPACTS RELATED TO THE ANTHROPIC ENVIRONMENT}

\section{Temporary migration}

Portion of the workforce required for the implementation of the project should move to the area, often accompanied by members of their families. Since it is absorbed during the deployment phase, their stay must be temporary. I mean, after the completion of the project the population directly and indirectly involved in activities tends to migrate again. However, this fact may not fully occur, remaining some people in the area of influence of the project. Thus the flow and reflow of the population displacement always bring changes in the daily routine of the local community.

\section{Job generation}

In the implementation phase of the dredger, are generated direct jobs, involving skilled, unskilled and semi-skilled labor. This last region, it is of greater availability in the region of the enterprise, mainly in the nearby region.

It should be noted that the indirect jobs are generated in the period where the demand is high; such jobs will have a temporary effect, in other words, despite the positive effect that caused it, the exemption is always a new beginning. However, the multiplier effect of the generation and circulation of wealth can provide the emergence or strengthening of local activities.

\section{Risks of accidents with the workers}

The Personal Protective Equipment, necessary for the safety of workers, while carrying out its activities, operating machinery or dealing with oil, grease, dust and gases, must be available.

\section{MITIGATING MEASURES OF IMPACTS}

The ABNT (Associação Brasileira de Normas Técnicas) 1989 focuses on the defense of the environment stage by stage. It deals with soil recovery as an adverse change of pre-existing features, processing the handling with conditions for new uses, approaching the conditions prior to the intervention. It aims the rehabilitation of soil as a means of recovery when an area is suitable for a use, according to a previous 
project. And finally, seeks the recovery, including restoring, in an attempt to reproduce the exact original condition, as much as possible.

\section{Air Quality Change}

Periodic inspection and adjustment of machines and equipment; Use of car-pipa for soil damping in operations that promote strong dust emission; Implementation of transportation of materials subjected to dust emission, through use of protection/cargo coverage with appropriate pads in order to reduce pollution by dust, mainly in the vicinity of neighborhoods located in the vicinity of the enterprise; distribution and requirement of the use of Personal Protective Equipment - PPEs by workmen during the construction phase and deployment of the dredger.

\section{Production of noises and vibrations}

Periodic inspection and adjustment of machines and equipment; distribution and requirement of the use of the Personal Protective Equipment - PPE by workers during the dredger implementation and operation.

\section{Soil Quality Change}

Soil Interventions for cuts and landfills should prevent erosion processes. In cases where the areas near to the project, are already in areas already affected by erosion, the processes must be contained appropriately to not evolve and commit the new works; Retrieve the already degraded areas around the river, following the permanent preservation strip allowed in current legislation.

\section{Water Quality Change}

In obtaining water from various sources (surface water or groundwater), care should be taken, aiming its quality and quantity maintenance.

\section{Solid Waste Generation}

Adequately deposit the remains of materials from construction works and of the particulate material emitted by the operation of the dredger in send-off exist, such as the municipal dumps of the area of influence of the project.

Campaigns for workers about ways to package containers and leftovers of products, including those of personal use, in plastic bags so that they are later used for the 
municipal dumps of the area of influence of the project.

Removal of vegetation and site cleaning

When during the vegetation suppression and cleansing of the domain, provide suitable packaging of green mass on the domain strip must be provided. This procedure should be taken after the use of woody material (wood); the trees that do not interfere in the operation of the dredger should be left intact.

\section{Fauna Chasing}

Don't interfere on the trail of the animals present in the area during the cleaning process of the local domain to be explored. Orient employees to not collect chicks and eggs in the nests and other habitats. Speeches in favor of ecological awareness of officials in order to protect the local wildlife must be taken.

\section{Temporary Migration}

Disclose the operation of the dredger indirectly about its temporality and its implementation period to the involved population, in order that there might be a plan for their demobilization.

\section{Job Generation}

Hiring local labor as well as of the present near the site of the enterprise should be prioritized. Raise awareness of the local population that some jobs will be temporary. The entrepreneur should prioritize local procurement of auxiliary services such as: supply of oils and fuels, purchase of office and general materials consumption, warm food packages acquisition, etc.

\section{Increase in tax collection}

Communicate to the Government of the municipality involved about the beginning of the operation of the dredger, alerting him about the possible increase of revenue driven by implementation of the project.

\section{Change in the daily life of the community}

Clarify for the population on the temporality of the workmanship and the possibility of transmissible illnesses. Clarify for the dredge workers, about the influence that their 
behavior has on the community, requesting them to respect local customs and habits.

\section{Risk of accidents with the workers}

The use of Personal Protective Equipment - PPEs, such as: helmet, gloves, boots, mask, etc., on the part of workers linked directly to the implementation and operation of the dredger must be distributed and have their use demanded. Carry out workers' health inspection before hiring them. The training to workers on personal protective equipment will be needed.

\section{CONCLUSION}

Based on the results achieved, the following conclusions were collected:

The results show that the activity is feasible under the environmental, technical and economic point of view, and will bring benefits in the generation of jobs and income, as well as the provision of inputs to construction.

It should be noted that, although this mineral extraction will cause changes to the environment, the environmental control proposed measures will mitigate the impacts resulting from the activity, proposing the rehabilitation of mining area.

\section{REFERÊNCE BIBLIOGRAPHY}

ALMEIDA, Josimar Ribeiro de; AQUINO, Afonso Rodrigues de. (Colaborador). Perícia Ambiental Judicial e Securitária: Impacto, dano e passivo ambiental.

BRASIL, Legislação Federal Sobre o Meio Ambiente: Referências. Brasília, 1988, p.32.

BRASIL, Projeto RADAM. Levantamento de Recursos Naturais. Vol. 3. Folha SB. 23 - Teresina Rio de Janeiro, 1973.

CAMARGOS, J. A. A. et al. Instituto Brasileiro do Meio Ambiente e dos Recursos Naturais Renováveis, Laboratório de Produtos Florestais. Brasília: Ed. IBAMA, 2001. 896p. 
CARVALHO, C. G. de. Legislação Ambiental Brasileira. Contribuição para um Código Nacional do Ambiente. 2. ed. - Campinas: Millenium, 2002. 1v. 243p.

CITADINI-ZANATTE, V. et al. Composição Florística e Estrutura Fitossociológica do Componente arbustivo Arbóreo de um Remanescente de Floresta Ombrófila densa, Siderópolis, Santa Catarina. Disponível em <http:/www.ambientebrasil.com.br. Acesso em: 06 de julho de 2004.

CORREIA FILHO, F. L.; MOITA, J. H. A. Projeto Avaliação de Depósitos Minerais para a Construção Civil PI/MA. Teresina: CPRM, 1997

CUNHA, Sandra Baptista da. GUERRA, Antonio José Teixeira (orgs.). Avaliação e Perícia Ambiental. 2. ed. Rio de Janeiro: Bertrand Brasil, 2000. 294p.

Diagnóstico das Condições Ambientais do Estado do Piauí, Teresina, 1984, p. 332.

FUNDAÇÃO CEPRO - CD-ROM Piauí - informações municipais, 2000.

GUERRA, A. J. T.; SILVA, A. S. da.; BOTELHO, R. G. M. (Organizadores), Erosão e Conservação dos Solos: Conceitos, Temas e aplicações. Rio de Janeiro: Bertrand Brasil, 199. 340p

MACHADO, P. A. L. Direito Ambiental Brasileiro. 9 ed. Ver. Atual. e ampl. - São Paulo: Malheiros Editores, 2001.

MORAES, L. C. S. de. Código Florestal Comentado: com alterações da lei de crimes ambientais, Leri no 9.605/98. 2 ed. - São Paulo: Atlas, 2000.

MOTA, S. Preservação e Conservação de Recursos Hídricos. 2. ed. Ver. e atualizada. Rio de Janeiro: ABES, 1995. 200P.

PINTO, W. de. Legislação Federal do Meio Ambiente. Brasília: MMA/IBAMA, 1996.3 v.

PRIMACK, R. B; RODRIGUES, E. Biologia da Conservação. Londrina, 2001. 328p. 
SÉGUIN, Elida. Direito Ambiental: Nossa Casa Planetária. Rio de Janeiro: Forense, 2006.

SHULTZ, Alarich R. Estudo Prático da Botânica. Geral. 3 ed. Porto Alegre, Globo, 1972, p. 270.

TREVISOL, R. et al. Análise da Colonização Vegetal Espontânea em Ambientes Modificados por Medidas Físicas na Recuperação de Área Degradada, Seropédica (RJ). Acesso em: <http:/www.ambientebrasil.com.br. Acesso em: 06 de julho de 2004. 